\title{
Pathogenic Variability of Puccinia coronata f. sp. avenae and $P$. graminis f. sp. avenae on Oat in South Africa
}

\author{
B. D. van Niekerk, Agricultural Research Council, Small Grain Institute, Private Bag X29, Bethlehem 9700, South \\ Africa; Z. A. Pretorius, Department of Plant Pathology, University of the Free State, P.O. Box 339, Bloemfontein \\ 9300, South Africa; and W. H. P. Boshoff, Agricultural Research Council, Small Grain Institute, Private Bag X29, \\ Bethlehem 9700, South Africa
}

\begin{abstract}
van Niekerk, B. D., Pretorius, Z. A., and Boshoff, W. H. P. 2001. Pathogenic variability of Puccinia coronata f. sp. avenae and P. graminis f. sp. avenae on oat in South Africa. Plant Dis. 85:1085-1090.

Although crown rust (caused by Puccinia coronata f. sp. avenae) and stem rust (caused by Puccinia graminis $\mathrm{f}$. sp. avenae) are generally considered to be the most widespread and damaging diseases of oat (Avena spp.) in South Africa, pathogenic variability has never been studied. During 1997 and 1998, one dominant crown rust pathotype (SBLL) was identified with virulence to resistance genes $P c 40, P c 45, P c 46, P c 51$, and $P c 54$. Four other pathotypes (SGLL, $\mathrm{PBBB}+P c 35, \mathrm{SDQL}$, and $\mathrm{JBBM}+P c 35)$, occurring at low frequencies and further rendering resistance genes $P c 35, P c 39, P c 48, P c 50, P c 52$, and $P c 64$ ineffective, were also detected. Resistance gene $P c 40$ was postulated in Wisconsin X1588-2; Pc51 in Euro, Maluti, Overberg, OX88I 075-106, Perdeberg, and Swartberg; and Pc39 was confirmed in the cultivar Fidler. During the same period, four stem rust pathotypes were identified with virulence to resistance genes $P g 1, P g 2, P g 4, P g 8, P g 9, P g 12, P g 15$, and $P g a$. Resistance gene $P g a$ was postulated in Alpha, OX87 080-1, OX88I 075-106, Sederberg, and W94/4; Pg2 and/or Pg4 in Euro, Perdeberg, Potberg, and Swartberg; and $P g 9$ in Pallinup and Victorian. Collections of wild oat species Avena fatua, A. byzantina, A. sterilis, and A. barbata were susceptible to all crown rust pathotypes, while the four stem rust pathotypes were virulent on all species except $A$. barbata.
\end{abstract}

Oat (Avena sativa L.) is an important cereal, used both for human consumption and as a feed grain, and ranks sixth in world cereal production after wheat, maize, rice, barley, and sorghum (22). Crown (leaf) rust, caused by Puccinia coronata Corda f. sp. avenae Eriks., has been considered the most important fungal disease of cultivated oat (30), while stem rust, caused by Puccinia graminis Pers.:Pers. f. sp. avenae Eriks. \& E. Henn., occurs in most of the oat growing areas of the world, periodically causing severe crop losses $(18,19,30)$.

$P$. coronata $\mathrm{f}$. sp. avenae is highly variable in virulence and can rapidly evolve new pathotypes that overcome commonly used resistance genes $(7,17,30)$. Early studies on pathogenic variability in $P$. graminis f. sp. avenae indicated that different virulence combinations occurred widely. As new genes for resistance were discovered, virulence on them was usually found concurrently, and in most cases, virulence to these genes was present in the pathogen

Corresponding author: B. D. van Niekerk

E-mail: Danie@KGS1.AGRIC.ZA

Accepted for publication 19 June 2001.

Publication no. D-2001-0810-01R

(C) 2001 The American Phytopathological Society population before cultivars with the genes were grown over large areas (19).

In South Africa, Sawer (28) reported in 1909 that oat crops in KwaZulu-Natal were destroyed to such an extent by crown rust that oat could no longer be grown there. Sawer (28) also provided evidence of dramatic changes in cultivar disease rankings over time which, although speculative, could have been due to pathogenic adaptation. Evans (11) reported that oat rust was not known in South Africa before 1858 but that the disease had often restricted production during the latter part of the nineteenth century. Although records of collections of $P$. graminis (host and forma specialis unknown) in 1874 exist (4), Bailey was the first to identify a race of $P$. graminis f. sp. avenae in South Africa in 1925 (19), while Verwoerd (35) identified two "forms" of $P$. graminis f. sp. avenae, with "form 2" resembling the race identified by Bailey. According to Doidge (9) and Verwoerd $(33,34)$, P. graminis f. sp. avenae was found on oat throughout South Africa, and reference was made to the occurrence of $P$. coronata $\mathrm{f}$. sp. avenae from Stellenbosch in the south to as far north as Salisbury, Rhodesia (now Harare, Zimbabwe). Doidge et al. (10) reported that no aecidial form is known for crown rust in South Africa.

Currently, oat production is completely deregulated in South Africa, and no official records of the total area cultivated or annual production exist. Oat is used for various purposes, including oat grain for breakfast cereal, horse feed, general feed rations, health foods, and bird feed. In the Western Cape, oat is planted primarily for silage, whereas it is grown as green feed during the dry winter months in the summer rainfall areas. In 1991, the Small Grain Institute conducted a survey among 27 agricultural cooperatives and established that $8.6 \%$ of cultivated oat was used for grain production, $76.4 \%$ for grazing, and $15 \%$ for silage. According to this survey, seed sales suggested that 59,620 ha of oat were planted during 1990. This is probably a conservative estimate because many farmers retain their own seed, especially when oat is grown for grazing purposes. At present, oat has also increased in popularity as a rotation crop under irrigation and as grazing in the Highveld. W. Engelbrecht (report presented at the meeting of the South African National Seed Organisation, 12 to 14 May 1999) estimated the potential for oat production in South Africa to be $\pm 700,000$ ha.

Historically, most oat cultivars in South Africa have been susceptible to crown rust. In association with stem rust, crown rust is often responsible for significant losses in oat seed quantity and quality. Although both pathogens occur annually in most oat growing areas of South Africa, rust diseases are especially severe in the Western Cape. Occasionally, severe epidemics will occur in the summer rainfall area, e.g., the widespread crown rust infections experienced in the Free State during 1998.

The objectives of this study were to determine the pathogenic variability in $P$. coronata f. sp. avenae and $P$. graminis $\mathrm{f}$. sp. avenae in South Africa and to establish representative pathotypes for further testing of germ plasm. Oat cultivars and breeding lines were also evaluated for seedling and adult plant resistance toward both diseases, whereas the role of wild Avena spp. as possible accessory hosts for both crown and stem rust was also investigated.

\section{MATERIALS AND METHODS}

Survey and pathotype differentiation. Oat leaves and stems infected with either $P$. coronata f. sp. avenae or $P$. graminis $\mathrm{f}$. sp. avenae were collected from trap nurser- 
ies, commercial fields, and wild oat during the 1997 and 1998 annual rust surveys conducted by the Small Grain Institute. Urediniospores were removed from infected leaves and stems using a cyclone spore collector and stored in gelatin capsules at $-70^{\circ} \mathrm{C}$. Upon retrieval from lowtemperature storage prior to inoculation, spores were given a heat treatment of 6 min at $47^{\circ} \mathrm{C}$. Oat seedlings for purifying field samples were raised in a disease-free growth chamber at a continuous temperature of $22^{\circ} \mathrm{C}$ and $14 \mathrm{~h}$ of light provided by cool-white fluorescent tubes and incandescent bulbs arranged $30 \mathrm{~cm}$ above plants and emitting $200 \mu \mathrm{E} \cdot \mathrm{m}^{-2} \cdot \mathrm{s}^{-1}$ of photosynthetically active radiation. Seedlings were grown in 10-cm-diameter plastic pots filled with steam-sterilized soil and treated with $50 \mathrm{ml}$ per pot of a $0.3 \mathrm{~g} \mathrm{liter}^{-1}$ maleic hydrazide solution to retard plant development and stimulate sporulation.

Using light mineral oil (Soltrol 170) as carrier medium, urediniospores of $P$. coronata $\mathrm{f}$. sp. avenae and $P$. graminis $\mathrm{f}$. sp. avenae were inoculated onto 7-day-old (first leaf fully extended) Overberg or Swan seedlings, respectively. Overberg was selected for this purpose due to its historic susceptibility to crown rust. Likewise, Swan has been reported to carry no genes for resistance to $P$. graminis $\mathrm{f}$. $\mathrm{sp}$. avenae (2). Seedlings were allowed to dry for $1 \mathrm{~h}$ in fan-circulated air at room temperature before being placed in the dark in a dew simulation chamber at $18^{\circ} \mathrm{C}\left( \pm 2^{\circ} \mathrm{C}\right)$ for $18 \mathrm{~h}$. After removal from the dew chamber, plants were allowed to dry for 2 $\mathrm{h}$ before placement in a greenhouse. Throughout this study, the collection of spores and inoculation of seedlings were done as described by Browder (5). Plants inoculated with different isolates were placed in separate glass compartments to avoid contamination. Greenhouse temperatures were maintained at $22^{\circ} \mathrm{C}$ for crown rust and $19^{\circ} \mathrm{C}$ for stem rust studies, with natural daylight supplemented by $14 \mathrm{~h}$ of $120 \mu \mathrm{E} \cdot \mathrm{m}^{-2} \cdot \mathrm{s}^{-1}$ photosynthetically active radiation emitted by cool-white fluorescent tubes arranged directly above the plants. After 10 to 14 days, two to four single pustules per sample were collected, increased on either Overberg or Swan, and inoculated onto the respective differential sets (entries listed in Tables 1 and 2). Three to four days after the initial eruption of uredia, infection types were assessed using a 0 to 4 scale (26). P. coronata f. sp. avenae infection types were assessed on the adaxial surfaces of leaves, whereas those of $P$ graminis f. sp. avenae were rated on abaxial surfaces. Pathotype designations were allocated according to Chong et al. (8).

The adult plant reactions of the various differentials were also determined. Crown and stem rust differential lines were planted in an unreplicated screening nursery at Bethlehem during the 1998 season. Entries were sown in 1-m rows spaced 17 $\mathrm{cm}$ apart and bordered by two rust spreader rows consisting of a mixture of Makuru, Maluti, Pallinup, Euro, and Overberg. When the first spreader plants reached growth stage 36 (36), equal amounts of urediniospores of crown rust pathotype SBLL and stem rust pathotypes SAPga 1, SAPga 2, SAPga 3, and SAPga 4 suspended in water with the aid of Tween 20 were injected into tillers. When infected flag leaves appeared in spreader rows, disease progress was assisted by overhead mist irrigation at night. During the course of the epidemic, disease reactions were assessed using a modified Cobb scale (24).

Cultivar reaction. The disease reactions of all oat cultivars grown in South Africa, as well as advanced breeding lines, were determined in the seedling stage to crown rust pathotypes SBLL, SGLL, PBBB+ Pc35, SDQL, and JBBM+Pc35, as well as stem rust pathotypes SAPga 1, SAPga 2, SAPga 3, and SAPga 4. Four cultivarslines were planted in clumps of approximately 10 seeds each in a $10-\mathrm{cm}$ plastic pot filled with steam-sterilized soil. When first leaves were fully expanded, plants were inoculated with freshly collected urediniospores of the different pathotypes. Inoculation and incubation procedures were similar to those described previously. Reaction patterns were interpreted for postulation of resistance genes.

Crown and stem rust severity were assessed (modified Cobb scale) on entries in the annual oat cultivar adaptation trials conducted in the main production areas by

Table 1. Infection types ${ }^{\mathrm{a}}$ produced on seedlings of differential lines of Avena sativa containing single $P c$ genes when infected with pathotypes SBLL, SGLL, PBBB $+P c 35$, SDQL, and JBBM $+P c 35$ of Puccinia coronata $\mathrm{f}$. sp. avenae

\begin{tabular}{|c|c|c|c|c|c|c|}
\hline \multirow[b]{2}{*}{$P c$ gene } & \multirow[b]{2}{*}{ Tester line } & \multicolumn{5}{|c|}{ P. coronata f. sp. avenae pathotypes } \\
\hline & & SBLL & SGLL & PBBB + Pc35 & SDQL & $\mathrm{JBBM}+P c 35$ \\
\hline Pc35 & D137/2*Pendek ${ }^{\mathrm{b}}$ & $; 1 \mathrm{CN}$ & ;N & $2+3$ & ;C & $2+3$ \\
\hline Pc38 & CAV $2648-4 / 4 *$ Pendek $^{\mathrm{c}}$ & 0 & ; & ;C & 0 & ;C \\
\hline Pc39 & CAV 5165/4*Pendek ${ }^{\mathrm{c}}$ & ; & 3 & ; & ; & ;C \\
\hline Pc40 & Pendek2*/CAV $4997^{c}$ & $2+3$ & 3 & 3 & $2+3$ & ;C \\
\hline Pc45 & Pendek*4/CAV 5050 & $2+3$ & $2+3$ & ; & $2+3$ & 3 \\
\hline Pc46 & Pendek*4/CAV $5115^{\mathrm{c}}$ & $2+3$ & $2+3$ & $2+3$ & $2+3$ & $2+3$ \\
\hline Pс48 & Pendek $2 * /$ CAV $5041^{\text {c }}$ & $; \mathrm{C}$ & ; & ; & $2+3$ & $; \mathrm{C}$ \\
\hline Pc50 & CAV 2643/4*Pendek ${ }^{c}$ & ; & ; & $2+3$ & 0 & 0 \\
\hline Pc51 & Iowa Early isoline X-434 c & $2+3$ & 3 & ; & $2+3$ & $;$ \\
\hline Pc52 & Iowa Midseason isoline X-421 & ;C & ; & 0 & $2+3$ & ; \\
\hline$P c 54$ & Pendek $* 2 /$ CAV $1832^{c}$ & $2+3$ & $2+3$ & ;C & $2+3$ & $2+3$ \\
\hline Pc56 & CAV 1964/4*Pendek ${ }^{c}$ & $; 1=\mathrm{C}$ & ;C & ;C & ;C & $X(;, 2)$ \\
\hline Pc58 & TAM-O-301 (P.I. 295919) ${ }^{\mathrm{c}}$ & ; & ; & $\mathrm{X}(; \mathrm{C}, 2)$ & ;C & $X(;, 2)$ \\
\hline Pc59 & TAM-O-312 (P.I. 296244) ${ }^{\mathrm{c}}$ & ; & ; & ; & $;$ & ; \\
\hline Pc60 & Coker $227^{d}$ & $2 \mathrm{C}$ & $2 \mathrm{C}$ & $\mathrm{X}(;, 2 \mathrm{C})$ & ;C & $X(;, 2)$ \\
\hline Pc61 & Coker $234^{\mathrm{d}}$ & $2 \mathrm{C}$ & $2 \mathrm{C}$ & ; & ; & $X(;, 2)$ \\
\hline Pc62 & Fraser*2/CAV $4274^{c}$ & $; 1 \mathrm{CN}$ & $; 1$ & ;C & ;C & $X(;, 2)$ \\
\hline Pc63 & Fraser*2/CAV $4540^{\mathrm{e}}$ & ; & ; & ; & 0 & $; \mathrm{C}$ \\
\hline Pc64 & Makuru*2//CAV4248/2*Sun II & ; & ; & ; & ; & 3 \\
\hline Pc68 & Makuru*2//CAV4904/2*Sun II ${ }^{c}$ & 0 & 0 & 0 & 0 & 0 \\
\hline Pc94 & $\mathrm{S} 42^{\mathrm{f}}$ & ; & 0 & 0 & 0 & 0 \\
\hline Pc96 & RL $1730^{\mathrm{g}}$ & 0 & ; & 0 & 0 & $X$ \\
\hline
\end{tabular}

${ }^{a}$ Roelfs (26).

${ }^{\mathrm{b}} \mathrm{Kiehn}$ et al. (16).

${ }^{c}$ Chong et al. (8). It should be noted that Kiehn et al. (16) listed the Avena sterilis donor lines of Pc38, Pc40, and Pc50 as CAV 2468, CAV 4997, and CAV 2463, respectively.

${ }^{\mathrm{d}}$ Simons et al. (31).

e Harder et al. (15).

${ }^{\mathrm{f}}$ Aung et al. (3); pedigree of S42 is SunII/RL1697.

$\mathrm{g}$ Chong and Brown (6). 
the agronomy department of the Small Grain Institute. These replicated trials consisted of commercial cultivars as well as the most promising breeding lines.

Accessory hosts. Several Avena spp., including A. fatua, A. byzantina, A. sterilis, and $A$. barbata, occur in South Africa, with A. fatua being the most common (32). Collections of these species were evaluated for seedling resistance to all the pathotypes of $P$. coronata f. sp. avenae and $P$. graminis f. sp. avenae detected during the study period. Procedures for growing of plants as well as inoculation and disease assessment were as described above.

\section{RESULTS}

Crown rust. During 1997, 11 samples were collected from the south Western Cape, 14 from the Western Cape, six from KwaZulu-Natal, and 17 from the Free State. During 1998, 15 samples were received from each of the south Western Cape and Western Cape regions, respectively, and five from KwaZulu-Natal and 13 from the Free State. In total, 269 singlepustule isolates were tested on differential sets, revealing one dominant pathotype (SBLL) and four others (SGLL, $\mathrm{PBBB}+P c 35, \mathrm{SDQL}$, and $\mathrm{JBBM}+P c 35)$ detected at low frequencies only (Table 1).
In field tests, lines with Pc40, 45, 46, 51 , and 54 displayed severities of more than $80 \mathrm{~S}$, while lines with Pc60 and Pc61 had severities of 20MRMS and 15MRMS, respectively. All other $P c$ lines were completely resistant (data not shown).

Stem rust. During 1997, 59 samples were collected, six from the Western Cape, 16 from the south Western Cape, and 37 from the Free State. During 1998, 18 samples were collected from the south Western Cape, seven from the Western Cape, four from KwaZulu-Natal, 13 from the Free State, and two from Lesotho. These collections resulted in the establishment and differentiation of 242 single-pustule isolates. From these, pathotypes SAPga 1 $(P g 3,9,10,13,16, a / 1,2,4,8,15), \quad$ SAPga 2 $(3,10,13,16, a / 1,2,4,8,9,15), \quad$ SAPga 3 $(2,3,4,9,10,13,16, a / 1,8,15)$, and SAPga 4 $(3,10,13,16 / 1,2,4,8,9,15, a)$ were identified (Table 2). The avirulence-virulence formulae of each pathotype are shown as proposed by Martens et al. (21). During $1997,43.1 \%$ of the isolates belonged to pathotype SAPga 1 and $30.4 \%$ to SAPga 4. Pathotypes SAPga 3 and SAPga 2 represented 22.4 and $4.1 \%$ of the isolates, respectively. In 1998, pathotype SAPga 4 was isolated most frequently (67.7\%), followed by SAPga 1 (17.1\%),
SAPga $3(9.2 \%)$, and SAPga $2(6.1 \%)$ (Table 3).

In the field, high (50S to 80MS S) stem rust severities on lines containing either $P g a, 1,4,9,15,1+2,2+4$, or $4+5$ were recorded. Although virulence occurred for $P g 2$ in seedling tests, this line was not heavily rusted (30MS) under field conditions.

Cultivar reaction. Cultivars and advanced breeding lines were evaluated in the seedling stage for their reaction to crown rust pathotypes SBLL, SGLL, $\mathrm{PBBB}+P c 35$, SDQL, and $\mathrm{JBBM}+P c 35$ (Table 4) and stem rust pathotypes SAPga 1, SAPga 2, SAPga 3, and SAPga 4 (Table 5). The South African cultivars Drakensberg, Kompasberg, Sederberg, and Tafelberg were resistant to all crown rust pathotypes tested, and high levels of stem rust resistance were displayed by Drakensberg. Adult plant reactions of oat elite lines to natural infections of crown and stem rust during the 1999 season are given in Table 6. Similar to the seedling responses, Sederberg, Kompasberg, and Tafelberg were resistant to crown rust in the field. Line OX87:073-10-14 was the only entry not showing any stem rust symptoms. Because of the longer growth period and cold requirement of Drakensberg, this cultivar

Table 2. Infection types ${ }^{\mathrm{a}}$ produced on seedlings of differential lines of Avena sativa containing single $P g$ genes as well as gene combinations by pathotypes SAPga 1, SAPga 2, SAPga 3, and SAPga 4 of Puccinia graminis f. sp. avenae

\begin{tabular}{|c|c|c|c|c|c|}
\hline \multirow[b]{2}{*}{$P g$ gene } & \multirow{2}{*}{$\begin{array}{l}\text { CI number/ } \\
\text { line designation }\end{array}$} & \multicolumn{4}{|c|}{ P. graminis f. sp. avenae pathotypes } \\
\hline & & SAPga 1 & SAPga 2 & SAPga 3 & SAPga 4 \\
\hline$P g a$ & Rodney-0/Pga ${ }^{\mathrm{b}}$ & ; & ; & ; & 3 \\
\hline Pgl & $\mathrm{CI} 9318^{\mathrm{c}}$ & $2+3$ & $2+3$ & $2+3$ & 3 \\
\hline Pg2 & CI $9319^{c}$ & 3 & 3 & ; & 3 \\
\hline Pg3 & CI $9320^{c}$ & $\mathrm{X}$ & 2 & $\mathrm{X}_{-}$ & 2 \\
\hline Pg4 & CI $6661^{\mathrm{c}}$ & 3 & 3 & 0 & 3 \\
\hline $\operatorname{Pg} 8$ & CI $9321^{\mathrm{c}}$ & 3 & 3 & 3 & 3 \\
\hline $\operatorname{Pg} 9$ & CI $9322^{c}$ & ;2 & $2+3$ & $; 1$ & 3 \\
\hline Pg 10 & X1588-2/2*Makurub & 0 & $X_{-}$ & 0 & ;C \\
\hline Pgl3 & CI $9212^{\mathrm{c}}$ & ; & $; 1$ & ;C & $; 1 \mathrm{C}$ \\
\hline Pg15 & CI $9351^{\mathrm{c}}$ & $2+3$ & $2+3$ & 3 & 3 \\
\hline Pgl6 & CI $9352^{\mathrm{c}}$ & ;C & ; & $X_{-}$ & ;C \\
\hline $\operatorname{Pg} 17$ & IB3056/2* Makuru ${ }^{\mathrm{d}}$ & $2+3$ & $2+3$ & $2+3$ & 3 \\
\hline$P g 1+2$ & Minn. Ag. $331^{\mathrm{e}}$ & 3 & 4 & ; & 3 \\
\hline$P g 2+4$ & Garry & 3 & 4 & ; & 3 \\
\hline $\mathrm{Pg} 4+8$ & $P g 4+8$ line $^{\mathrm{e}}$ & $2+3$ & $2+3$ & ; & 3 \\
\hline$P g 2+4+9$ & Can-Ot-184e & $\mathrm{X}$ & $2+3$ & ; & 3 \\
\hline
\end{tabular}

a Roelfs (26).

${ }^{\mathrm{b}}$ Harder (12); Martens et al. (21) listed Avena sterilis S-66AB667/Kyto as the original source of Pga resistance.

${ }^{\mathrm{c}}$ Martens et al. (20).

${ }^{\mathrm{d}}$ Harder et al. (14). $P g 17$ confers adult plant resistance and was not used as a differentiating line.

e Adhikari (1).

Table 3. Distribution of Puccinia graminis f. sp avenae pathotypes in South Africa during 1997 and 1998

\begin{tabular}{|c|c|c|c|c|c|c|c|c|}
\hline \multirow[b]{2}{*}{ Region } & \multicolumn{4}{|c|}{1997} & \multicolumn{4}{|c|}{1998} \\
\hline & SAPga 1 & SAPga 2 & SAPga 3 & SAPga 4 & SAPga 1 & SAPga 2 & SAPga 3 & SAPga 4 \\
\hline Western Cape & $48.4^{\mathrm{a}}$ & 7.9 & 23.8 & 19.9 & 9.8 & 1.2 & 6.2 & 82.8 \\
\hline South Western Cape & 40.1 & 4.2 & 21.3 & 34.4 & 7.3 & 1.3 & 5.6 & 85.8 \\
\hline Free State & 43.5 & 3.4 & 22.7 & 30.4 & 30.5 & 2.3 & 15.6 & 51.6 \\
\hline KwaZulu Natal & $\ldots$ & $\ldots$ & $\ldots$ & $\ldots$ & 38.4 & 1.2 & 14.2 & 46.2 \\
\hline Lesotho & $\ldots$ & $\ldots$ & $\ldots$ & $\ldots$ & 0 & 100 & 0 & 0 \\
\hline Total $^{\mathrm{b}}$ & 43.08 & 4.08 & 22.43 & 30.42 & 17.05 & 6.05 & 9.18 & 67.72 \\
\hline
\end{tabular}

a Percentage of isolates identified per region.

b Total percentage of isolates identified in survey. 
is not recommended for the winter rainfall area and was therefore not included in this trial.

Accessory hosts. Collections of $A$. fatua, A. byzantina, A. sterilis, and A. barbata were susceptible to all five pathotypes of $P$. coronata $\mathrm{f}$. sp. avenae, and all pathotypes of $P$. graminis f. sp. avenae were virulent on A. fatua, A. byzantina, and A. sterilis. Accessions of A. barbata were resistant to all stem rust pathotypes.

\section{DISCUSSION}

This survey showed the presence of one dominant crown rust pathotype, SBLL, with virulence to the resistance genes Pc40, Pc45, Pc46, Pc51, and Pc54, on cultivated and wild oat in South Africa during 1997 and 1998. This confirms the preliminary data of Pretorius et al. (25), who described the common occurrence of the same pathotype. Domination by a single pathotype is unusual since $P$. coronata f. sp. avenae is characterized worldwide by high levels of virulence diversity $(7,17,30)$. The origin of pathotypes SGLL, $\mathrm{PBBB}+P c 35$, and SDQL is uncertain. With the exception of JBBM $+P c 35$, which was collected from the Pc64 line included in a disease nursery near Riviersonderend in the Western Cape in 1999, no indication of their existence was obtained from the rating of differential lines under conditions of natural infection in the field. All four were initially detected in the greenhouse as single, susceptible-type pustules on host lines completely resistant to pathotype SBLL. Furthermore, the fact that two of these pathotypes were avirulent to Overberg, the cultivar on which field collections were originally increased, suggests that they may have arisen through mutation. It is also possible, however, that contaminant spores may have inadvertently been collected either from resistant $(; 1)$ or susceptible (33+) reactions on Overberg. Based on these results, it is clear that Overberg is not an appropriate host for increasing field collections of $P$. coronata $\mathrm{f}$. sp. avenae. The resistance of Overberg to pathotypes such as $\mathrm{PBBB}+P c 35$ and $\mathrm{JBBM}+P c 35$ will lead to biased results and not give an accurate description of pathogenic variability in South Africa.

Despite this, valuable information was obtained on which $P c$ genes are ineffective in South Africa. The pathotypes identified also made it possible to postulate or con- firm the occurrence of $P c 39$ in Fidler (7), $P c 40$ in Wisconsin X1588-2, and Pc51 in Euro, Maluti, Overberg, OX88I 075-106, Perdeberg, and Swartberg (Table 4). These postulations were based on the differential pathogenicity of tester isolates toward these genes.

Comparison of South African pathotypes of $P$. coronata $\mathrm{f}$. sp. avenae with those described from other parts of the world is difficult. The composition of differential sets as well coding systems often differs among countries. According to the fourdigit codes described by Chong et al. (8), none of the South African pathotypes resembled any of those from Mexico, the United States, or Canada. However, with regard to individual genes, virulence to Pc39, 40, 45, 46, 48, 51, 54, and 64 occurred in the latter countries as well as in South Africa. Although virulence to Pc38, $56,58,59,62$, and 68 has been reported elsewhere (8), these and other genes such as $P c 60,61,63,94$, and 96 remain effective in South Africa. From Australian and New Zealand survey data, virulence to $P c 38,39,58,59$, and 61 was common in 1998 and 1999, whereas virulence to Pc68 was also detected in 1999 (23).

Table 4. Infection types ${ }^{\mathrm{a}}$ produced on seedlings of South African cultivars as well as additional lines of Avena sativa by Puccinia coronata f. sp. avenae pathotypes SBLL, SGLL, PBBB $+P c 35$, SDQL, and JBBM $+P c 35$

\begin{tabular}{|c|c|c|c|c|c|}
\hline \multirow[b]{2}{*}{ Cultivars } & \multicolumn{5}{|c|}{$P$. coronata f. sp. avenae pathotypes } \\
\hline & SBLL & SGLL & PBBB+Pc35 & SDQL & $\mathrm{JBBM}+P c 35$ \\
\hline Alpha & $02+$ & $2+3$ & $2+3$ & $; 2$ & 2 \\
\hline Drakensberg & 0 & 0 & 0 & 0 & 0 \\
\hline Dumont & 0 & 0 & 0 & 0 & 0 \\
\hline Echidna & $2+3$ & $2+3$ & $2+3$ & $2+3$ & - \\
\hline Euro & $03(\mathrm{Y})$ & $2+3$ & ;C & $2+3$ & ;CN \\
\hline Fidler & ;C & $2+3$ & ;C & ;C & 0 \\
\hline Heros & $2+3$ & 3 & $2+3$ & 2 & $22+$ \\
\hline HJA81462 & $2+3$ & $2+3$ & $2+3$ & $22++$ & $22+$ \\
\hline JO1298 & $2+3$ & $2+3$ & $2+3$ & $2+3$ & $2+3$ \\
\hline Kompasberg & ; & 0 & ; & 0 & 0 \\
\hline Kyto & $2+3$ & $22+3$ & $2+3$ & $2+3$ & $22+$ \\
\hline Langeberg & $22+3$ & - & - & - & $22+$ \\
\hline Makura & $2++3$ & $2+3$ & $2+3$ & $22++$ & 2 \\
\hline Maluti & $2+3$ & 3 & 2 & 3 & $; 1 \mathrm{C}$ \\
\hline Overberg & $2+3$ & 3 & $; ; 1$ & 3 & $; 1$ \\
\hline OX87 080-1 & $2+3$ & $2+3$ & ; & 0 & 0 \\
\hline OX88 123-104 & ;C & $; 1 \mathrm{c}$ & ; & 0 & 0 \\
\hline OX88I 075-106 & $22+3$ & $2++\mathrm{C}$ & ;CN & $22+3(Y)$ & $0 ; \mathrm{CN}$ \\
\hline Pallinup & $; 22+3(\mathrm{Y})$ & $2++3$ & ;C & ; & ;CN \\
\hline Perdeberg & $2+3$ & $2++3$ & ; & $2+3$ & $; \mathrm{CN}$ \\
\hline Potberg & $2+3$ & $2++3$ & $2+3$ & $2+3$ & $22+3$ \\
\hline Sederberg & ; & 0 & ; & 0 & 0 \\
\hline Sisko & $2+3$ & $22+3$ & $2+3$ & 2 & $2++$ \\
\hline SSH421 & $22+$ & 2 & ;C 2 & ;2+3 (Y) & $; 12$ \\
\hline SSH423 & $2++3$ & $2+3$ & $2+3$ & $2+$ & $2+3$ \\
\hline Swan & $2+3$ & $2+3$ & 3 & 3 & $2+$ \\
\hline Swartberg & $2+3$ & 3 & ; & $23(\mathrm{Y})$ & ; \\
\hline Tafelberg & 0 & 0 & ; & 0 & 0 \\
\hline Texan & $2+3$ & 3 & 3 & $2+3$ & $2+3$ \\
\hline Veli & $22+3$ & 3 & 3 & $22+$ & $22+$ \\
\hline Victorian & $22+3$ & 3 & $2+3$ & $2+3$ & - \\
\hline Virma & $22+3$ & $2+3$ & $2+3$ & $22+$ & $2++$ \\
\hline Wisconsin X1588-2 & $22+3(Y)$ & $2++3$ & $2+3$ & $22+3$ & ;12 \\
\hline Witteberg & $22+3$ & $2+3$ & $2+3$ & $22+3$ & $2+3$ \\
\hline YTY & $2+3$ & $2+3$ & 3 & $2++3$ & $2++3$ \\
\hline W 94/4 & 0 & ;12 & ;C & ;C & 0 \\
\hline SWK001 & $2+3$ & $2+3$ & 3 & $2+3$ & $2+3$ \\
\hline
\end{tabular}

${ }^{a}$ Roelfs (26). 
The lack of extensive pathogenic specialization in the local crown rust population may be due to the historic cultivation of highly susceptible cultivars and the susceptibility in wild oats, exerting little selection pressure for adaptation onto the oat crown rust population. It is also possible that samples were not collected from a geographically representative area, that other variants occurring at low frequencies were not detected due to sampling procedures, or that the use of Overberg excluded them from multiplication in the greenhouse.

During 1997 and 1998, four pathotypes of $P$. graminis f. sp. avenae were identified. Virulence was identified to the resistance genes $P g 1, P g 2, P g 4, P g 8, P g 9$, $P g 12, P g 15$, and $P g a$, with only $P g 3$, $P g 10, P g 13$, and $P g 16$ remaining effective (Table 2). Pgl2 was not included in the differential set but is represented in the cultivar Kyto (Table 5) (2). The effectiveness of $P g 17$ to the South African rust population is not known. $\mathrm{Pg} 10$ was previously identified as a useful source of resistance (12), whereas Šebesta (29) reported a lower frequency of virulence towards $P g 13, P g a$, and Pgl6 in Eurasia. On the other hand, none of the named $P g$ genes remains effective in Australia (23).

The 1997 survey was dominated by pathotypes SAPga 1 (43.1\%) and SAPga 4 $(30.4 \%)$, whereas pathotype SAPga 4 prevailed $(67.7 \%)$ in 1998 . The common isolation of pathotype SAPga 4 can be explained partly by the widespread cultivation of the cultivar Sederberg (approximately $80 \%$ of oat production) in the Western Cape. Sederberg carries the resistance gene Pga and thus acts as a selective host for this pathotype, leading to biased sampling. This was confirmed since $37 \%$ of the samples producing pathotype SAPga 4 were originally collected from Sederberg. Significant amounts of inoculum occur annually on this autumn-sown variety. These spores are then carried to the interior of the country during late winter by frontal weather systems moving in a predominantly northeasterly direction. Young oat plants in the summer rainfall area are subsequently infected, adding to the widespread distribution of SAPga 4.

According to the seedling reaction of cultivars to pathotypes SAPga 1, SAPga 2, SAPga 3, and SAPga 4, the following resistance genes were postulated: $P g a$ in Alpha, OX87 080-1, OX88I 075-106, Sederberg, and W94/4; Pg2 and/or Pg4 in Euro, Perdeberg, Potberg, and Swartberg; and $P g 9$ in Pallinup and Victorian. According to Harder et al. (13) and Rothman (27), Wisconsin X1588-2 possesses resistance genes $P g 2, P g 4$, and $P g 10$. The data presented in this study show $\mathrm{Pg} 10$ to be highly effective (Table 2), while Wisconsin $\mathrm{X} 1588-2$ is susceptible to pathotypes SAPga 2, SAPga 3, and SAPga 4 but resistant to SAPga 1 (Table 5). At present, this discrepancy cannot be explained, and more tests with different seed stocks are necessary to interpret the $P g 10$ and Wisconsin $\mathrm{X} 1588-2$ responses.

The information and oat rust pathotypes provided in this study should enable South African cereal pathologists and breeders to

Table 5. Infection types ${ }^{\text {a }}$ produced on seedlings of South African cultivars and lines of Avena sativa by Puccinia graminis f. sp. avenae pathotypes SAPga 1, SAPga 2, SAPga 3, and SAPga 4

\begin{tabular}{|c|c|c|c|c|}
\hline \multirow[b]{2}{*}{ Cultivar } & \multicolumn{4}{|c|}{ P. graminis f. sp. avenae pathotypes } \\
\hline & SAPga 1 & SAPga 2 & SAPga 3 & SAPga 4 \\
\hline Alpha & ; & ;C & ;C & $2+3$ \\
\hline Drakensberg & ; & ;C 1C & ; & $; 1$ \\
\hline Dumont & ; & ;2- & $; 1$ & $; 1$ \\
\hline Echidna & $6 \mathrm{p} 2+312 \mathrm{p} 0$ & $2+3$ & $; 1 \mathrm{C}$ & $2+3$ \\
\hline Euro & $2+3$ & 3 & $; 1 \mathrm{C}$ & $2+3$ \\
\hline Fidler & $; 1$ & 2 & ;C & 2 \\
\hline Heros & $22+3$ & $22+3$ & $22+3$ & $2++$ \\
\hline HJA81462 & 3 & $2+3$ & $2+3$ & $22+3$ \\
\hline JO1298 & $2+3$ & $2+3$ & $2+3$ & $22+3$ \\
\hline Kompasberg & $; 1$ & $7 \mathrm{p} 2-10 \mathrm{p} 22+3$ & $2-\mathrm{C}$ & $9 \mathrm{p} 2-\mathrm{C} 6 \mathrm{p} 2+3$ \\
\hline Kyto & $8 \mathrm{p} 2+38 \mathrm{p}$ & $22+$ & $22+3$ & $22+3$ \\
\hline Langeberg & $2+3$ & - & $; 1$ & - \\
\hline Makura & 3 & 3 & $2+3$ & $2+2+3$ \\
\hline Maluti & $2+3$ & $2+3$ & $22+3$ & $2+3$ \\
\hline Overberg & $2+3$ & $2+3$ & $2+3$ & $2+3$ \\
\hline OX87 080-1 & $; 1$ & 2 & $; 1$ & $2+3$ \\
\hline OX88 123-104 & 2 & $2+3$ & $22+3$ & $2+3$ \\
\hline OX88I 075-106 & ; & ;C & 0 & $2+3$ \\
\hline Pallinup & $; 1$ & $22+$ & ; & $22+3$ \\
\hline Perdeberg & 3 & $22+3$ & 0 & $22+$ \\
\hline Potberg & $2+3$ & 3 & 0 & $2+3$ \\
\hline Sederberg & ;C & ;C & ; & $2+3$ \\
\hline Sisko & $2+3$ & $2+3$ & $2+3$ & $2+3$ \\
\hline SSH421 & $2+3$ & $2+3$ & $2+3$ & $22+3$ \\
\hline SSH423 & 3 & $2+3$ & $22+3$ & - \\
\hline Swan & 3 & $2+3$ & $2+3$ & $22+3$ \\
\hline Swartberg & 3 & $2+3$ & $; 1$ & $2+3$ \\
\hline Tafelberg & ; & 2 & $; 1-\mathrm{C}$ & $2+$ \\
\hline Texan & $2+3$ & $22+3$ & $2++$ & $22+3$ \\
\hline Veli & $2+3$ & $22+$ & $22+3$ & $22+3$ \\
\hline Victorian & ; & $2+3$ & 0 & $22+3$ \\
\hline Virma & $2+3$ & 3 & 3 & 3 \\
\hline Wisconsin X1588-2 & 2 & 3 & $22+3$ & $2++3$ \\
\hline Witteberg & 3 & $22+$ & $2+3$ & $22+3$ \\
\hline YTY & $22+3$ & $22+3$ & $22+3$ & $22+3$ \\
\hline W 94/4 & ; & $; 1$ & $; 1$ & 3 \\
\hline SWK001 & $2+3$ & $2+3$ & $2+3$ & $22+3$ \\
\hline
\end{tabular}

${ }^{a}$ Roelfs (26).

Table 6. Adult plant reactions $s^{\mathrm{a}}$ of various oat cultivars and lines to natural infection of Puccinia coronata f. sp. avenae and P. graminis f. sp. avenae at Tygerhoek and Piketberg (Western Cape) during 1999

\begin{tabular}{lccccc}
\hline & \multicolumn{2}{c}{ Crown rust reaction } & & \multicolumn{2}{c}{ Stem rust reaction } \\
\cline { 2 - 3 } \cline { 5 - 6 } Cultivar/line & Tygerhoek & Piketberg & & Tygerhoek & Piketberg \\
\hline Overberg & $60 \mathrm{~S}$ & $100 \mathrm{~S}$ & & $10 \mathrm{~S}$ & $10 \mathrm{~S}$ \\
OX90:123-11-17C & 0 & 0 & & $60 \mathrm{~S}$ & $60 \mathrm{~S}$ \\
Potberg & $50 \mathrm{~S}$ & $70 \mathrm{~S}$ & & TS & $10 \mathrm{~S}$ \\
Perdeberg & $60 \mathrm{~S}$ & $100 \mathrm{~S}$ & & $10 \mathrm{MR}-\mathrm{MS}$ & $10 \mathrm{~S}$ \\
Sederberg & 0 & 0 & & $80 \mathrm{~S}$ & $40 \mathrm{~S}$ \\
Pallinup & $80 \mathrm{~S}$ & $100 \mathrm{~S}$ & & $10 \mathrm{~S}$ & $30 \mathrm{~S}$ \\
Euro & $80 \mathrm{~S}$ & $100 \mathrm{~S}$ & & $40 \mathrm{~S}$ & $40 \mathrm{~S}$ \\
OX91:066-7RL & $5 \mathrm{MS}$ & 0 & & $30 \mathrm{~S}$ & $40 \mathrm{~S}$ \\
Heros & $30 \mathrm{MS}-\mathrm{S}$ & $70 \mathrm{~S}$ & & TS & $10 \mathrm{~S}$ \\
OX87:073-10-14 & 0 & 0 & & 0 & 0 \\
Kompasberg & 0 & 0 & & $10 \mathrm{~S}$ & $20 \mathrm{~S}$ \\
Tafelberg & 0 & 0 & & $10 \mathrm{MS}-\mathrm{S}$ & $20 \mathrm{~S}$ \\
OX87:072-13-3C & $\mathrm{OMS}$ & 0 & & TS & 0 \\
OX90:109-49CL & 0 & 0 & & $20 \mathrm{~S}$ & $50 \mathrm{~S}$ \\
\hline
\end{tabular}

a S, susceptible; MS, moderately susceptible; $R$, resistant; MR, moderately resistant; $t$, trace; 0 , no visible signs of disease (modified Cobb scale, Peterson et al. [24]). for resistance to $P$. coronata $\mathrm{f}$. sp. anticipated that this study will form the basis of selecting and releasing rust resistant oat cultivars in South Africa, and that the severe yield and quality losses cur- screen breeding material more comprehen- 
rently experienced will be minimized. It should be emphasized, however, that continual monitoring of these pathogens is necessary to provide meaningful contributions to oat rust control.

\section{ACKNOWLEDGMENTS}

The provision of the crown and stem rust differential lines by James Chong and Don Harder (Agriculture Canada, Cereal Research Centre, Winnipeg) is gratefully acknowledged.

\section{LITERATURE CITED}

1. Adhikari, K. N. 1996. Genetic studies of stem rust resistance in oat and triticale. Ph.D. thesis. University of Sydney, Sydney, Australia.

2. Adhikari, K. N., McIntosh, R. A., and Oates, J. D. 1999. Inheritance of stem rust resistant phenotype $P g-a$ in oats. Euphytica 105:143154.

3. Aung, T., Chong, J., and Leggett, M. 1996. The transfer of crown rust resistance gene Pc94 from a wild diploid to cultivated hexaploid oat. Cer. Rusts Powd. Mild. Bull. 24(Suppl.):167-171.

4. Berkeley, M. J. 1876. An enumeration of the fungi collected at the Cape of Good Hope during the stay of the English transit of Venus expedition in 1874. J. Bot., London, Vol. XIV (new series Vol. V):173-175

5. Browder, L. E. 1971. Pathogenic specialization in cereal rust fungi, especially Puccinia recondita f. sp. tritici: Concepts, methods of study and application. U.S. Dep. Agric. Tech. Bull. 1432.

6. Chong, J., and Brown, P. D. 1996. Genetic resistance to Puccinia coronata f. sp. avenae in two Avena sativa accessions. Can. J. Plant Pathol. 18:286-292.

7. Chong, J., and Kolmer, J. A. 1993. Distribution and virulence of Puccinia coronata $\mathrm{f}$. sp. avenae in Canada in 1992. Can. J. Plant Pathol. 16:64-67.

8. Chong, J., Leonard, K. J., and Salmeron, J. J. 2000. A North American system of nomenclature for Puccinia coronata f. sp. avenae. Plant Dis. 84:580-585.

9. Doidge, E. M. 1927. Preliminary study of South African rust fungi. Bothalia 2:1-228

10. Doidge, E. M., Bottomley, A. M., Van der Plank, J. E., and Pauer, G. D. 1953. A revised list of plant diseases in South Africa. Union S. Afr. Dep. Agric., Sci. Bull. 346:62.

11. Evans, I. B. P. 1911. South African cereal rusts, with observations on the problem of breeding rust-resistant wheat. J. Agric. Sci. 4:95-104.

12. Harder, D. E. 1999. Usefulness of gene $P g 10$ as a source of stem rust resistance in oat breeding. Phytopathology 89:1214-1217.

13. Harder, D. E., Chong, J., and Brown, P. D. 1995. Stem and crown rust resistance in the Wisconsin oat selection X1588-2. Crop Sci. 35:1011-1015.

14. Harder, D. E., Chong, J., Brown., P. D., and Martens, J. W. 1990. Inheritance of resistance to Puccinia coronata avenae and $P$. graminis avenae in an accession of Avena sterilis from Spain. Genome 33:198-202.

15. Harder, D. E., McKenzie, R. I. H., and Martens, J. W. 1980. Inheritance of crown rust resistance in three accessions of Avena sterilis. Can. J. Genet. Cytol. 22:27-33.

16. Kiehn, F. A., McKenzie, R. I. H., and Harder, D. E. 1976. Inheritance of resistance to Puccinia coronata avenae and its association with seed characteristics in four accessions of Avena sterilis. Can. J. Genet. Cytol. 18:717726.

17. Kolmer, J. A., and Chong, J. 1993. Distribution of virulence in two populations of Puccinia coronata $\mathrm{f}$. sp. avenae in Canada. Can. J. Bot. 71:946-950.

18. Martens, J. W. 1978. Stem rust of oats in Canada in 1977. Can. Plant Dis. Surv. 58:5152.

19. Martens, J. W. 1985. Oat stem rust. Pages 103-129 in: The Cereal Rusts. Vol. 2. A. P. Roelfs and W. R. Bushnell, eds. Academic Press, New York.

20. Martens, J. W., Roelfs, A. P., McKenzie, R. I. H., Rothman, P. G., Stuthman, D. D., and Brown, P. D. 1979. System of nomenclature for races of Puccinia graminis $\mathrm{f}$. sp. avenae. Phytopathology 69:293-294.

21. Martens, J. W., Rothman, P. G., McKenzie, R. I. H., and Brown, P. D. 1981. Evidence for complementary gene action conferring resistance to Puccinia graminis avenae in Avena sativa. Can. J. Genet. Cytol. 23:591-595.

22. Murphy, J. P., and Hoffman, L. A. 1992. The origin, history, and production of oat. Pages 1-28 in: Oat Science and Technology. H. G. Marshall and M. E. Sorrells, eds. American Society of Agronomy Inc. and Crop Science Society of America Inc., Madison, WI.

23. Park, R. F. and Whale, M. 2000. 1998-99 Cereal Rust Survey Annual Report. Plant Breeding Institute, Cobbitty, University of
Sydney, Australia.

24. Peterson, R. F., Cambell, A. B., and Hannah, A. E. 1948. A diagrammatic scale for estimating rust intensity of leaves and stems of cereals. Can. J. Res. 26:496-500.

25. Pretorius, Z. A., van Niekerk, B. D., and Boshoff, W. H. P. 1998. Pathogenic variation in Puccinia coronata f. sp. avenae in South Africa. (Abstr.) S. Afr. J. Sci. 94, 11:xx.

26. Roelfs, A. P. 1988. Genetic control of phenotypes in wheat stem rust. Annu. Rev. Phytopathol. 26:351-367.

27. Rothman, P. G. 1984. Registration of four stem rust and crown rust resistant oat germplasm lines. Crop Sci. 24:1217-1218.

28. Sawer, E. R. 1909. The cereals in South Africa. Cedara Memoirs S. Afr. Agric. 1:264272.

29. Šebesta, J., Zwartz, B., Roderick, H. W. Harder, D. E., Corazza, L., and Stojanovic, S. 1998. Incidence of oat stem rust and virulence of Puccinia graminis Pers. f. sp. avenae Erikss. et Henn. on oat and the effectiveness of resistance in Europe during 1988 to 1996 Arch. Phytopathol. Plant Prot. 31:393-413.

30. Simons, M. D. 1985. Crown rust. Pages 131 172 in: The Cereal Rusts. Vol. 2. A. P. Roelfs and W. R. Bushnell, eds. Academic Press, New York.

31. Simons, M. D., Martens, J. W., McKenzie, R. I. H., Nishiyama, I., Sadanaga, K., Sebesta, J., and Thomas, H. 1978. Oats: A standardized system of nomenclature for genes and chromosomes a catalogue of genes governing characters. U.S. Dep. Agric. Handb. 509.

32. Smit, H. A. 1993. Die verdraagsaamheid van wildehawer vir onkruiddoders (The tolerance of wild oat to herbicides). Ph.D. thesis. University of the Orange Free State, South Africa.

33. Verwoerd, L. 1929. A preliminary checklist of diseases of cultivated plants in the winter rainfall area of the Cape province. Union $\mathrm{S}$. Afr. Dep. Agric., Sci. Bull. 88:1-28.

34. Verwoerd, L. 1931. A preliminary list of fungi from the Bloemfontein district of the Orange Free State. S. Afr. J. Sci. XVIII:298-301.

35. Verwoerd, L. 1931. Die fisiologiese vorms van Puccinia graminis Pers. wat in SuidAfrika voorkom (The physiological forms of Puccinia graminis Pers. that occur in South Africa). S. Afr. J. Sci. 28:274-279.

36. Zadoks, J. C., Chang, T. T., and Konzak, C. F. 1974. A decimal code for the growth stages of cereals. Weed Res. 14:415-421. 